\title{
Pengaruh Pelatihan dan Beban Kerja Terhadap Kinerja Pokja di Lingkungan Biro Pengadaan Barang dan Jasa Pemerintah Provinsi Lampung
}

\author{
Andy Fitriyadi Dharma Tilaar* \\ Sekolah Tinggi Ilmu Ekonomi Gentiaras, Lampung \\ *email: ms006zeta2001@yahoo.com
}

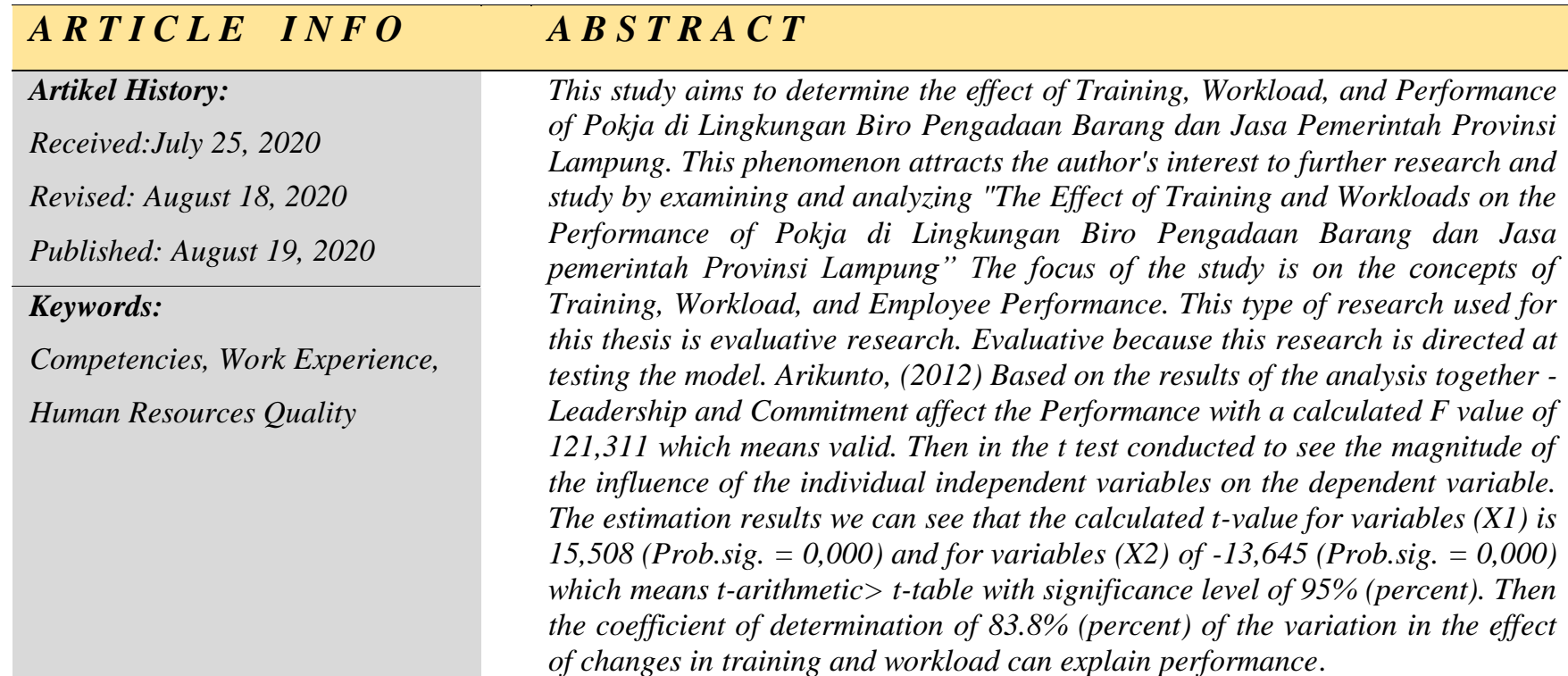

\section{N F O A R T I K E L A B S T R A K}

Riwayat Artikel:
Diterima: 25 Juli 2020
Direvisi: 18 Agustus 2020
Dipublikasikan: 19 Agustus 2020

Kata kunci:

Kompetensi,

Pengalaman Kerja, Kualitas SDM
Penelitian ini bertujuan untuk mengetahui pengaruh Pelatihan, Beban Kerja, dan Kinerja Pokja di Lingkungan Biro Pengadaan Barang dan Jasa Pemerintah Provinsi Lampung. Fenomena ini menarik minat penulis untuk meneliti dan mengkaji lebih lanjut dengan cara menguji dan menganalisis "Pengaruh Pelatihan dan Beban Kerja Terhadap Kinerja Pokja di Lingkungan Biro Pengadaan Barang dan Jasa pemerintah Provinsi Lampung". Fokus penelitian pada konsep Pelatihan, Beban Kerja, dan Kinerja Pegawai. Jenis penelitian yang digunakan untuk tesis ini adalah penelitian evaluatif. Bersifat evaluatif karena penelitian ini diarahkan pada pengujian model. Arikunto, (2012) Berdasarkan hasil analisis secara bersama - sama Kepemimpinan dan Komitmen berpengaruh terhadap Kinerja dengan nilai $\mathrm{F}$ hitung sebesar 121.311 yang berarti sahih. Kemudian pada uji t yang dilakukan untuk melihat besarnya pengaruh secara individu variabel bebas terhadap variabel tak bebas. Hasil estimasi dapat kita lihat bahwa nilai t-hitung untuk variabel $(\mathrm{X} 1)$ sebesar 15.508 (Prob.sig. $=0,000)$ dan untuk variabel (X2) sebesar -13.645 (Prob.sig. = 0,000) yang berarti t-hitung $>$ t-tabel dengan tingkat signifikansi $95 \%$ (persen). Kemudian koefisien determinasi sebesar $83,8 \%$ (persen) dari variasi perubahan pengaruh Pelatihan dan Beban Kerja dapat menjelaskan Kinerja. 


\section{PENDAHULUAN}

Kondisi perubahan jaman dan tuntutan kebutuhan, organisasi dihadapkan pada berbagai masalah dan tantangan baru. Kemajuan teknologi telah mengubah sifat dan kompetensi pelaksanaan tugas dari proses rekrutmen pegawai yang tentu memberikan harapan bagi organisasi dalam mendapatkan pegawai yang memiliki kompetensi, keahlian dan perilaku yang baik untuk mendukung pencapaian organisasi. Kompetensi, keahlian dan perilaku yang dimiliki pegawai tersebut harus dipertahankan dan dikembangkan lagi, oleh karena itu pelatihan perlu diberikan kepada pegawai agar dapat menyesuaikan dengan perkembangan teknologi dan perubahan global.

Dalam penelitian ini, penulis melakukan observasi awal pada Pokja di Lingkungan Biro Pengadaan Barang dan Jasa Pemerintah Provinsi Lampung. Penulis mendapatkan data pra riset dari organisasi tersebut. Berikut di bawah ini keterangan tabel pegawai yang telah mengikuti pelatihan dalam waktu 5 (lima) tahun terakhir.

Tabel 1. Pegawai yang pernah mengikuti pelatihan kerja dalam 5 tahun terakhir

\begin{tabular}{ccc}
\hline \multirow{2}{*}{ Tahun } & \multicolumn{2}{c}{ Pekerjaan } \\
\cline { 2 - 3 } & Jumlah Pelatihan & Mengikuti \\
\hline 2015 & 2 & 4 \\
2016 & 3 & 6 \\
2017 & 2 & 5 \\
2018 & 3 & 9 \\
2019 & 4 & 7 \\
\hline
\end{tabular}

Sumber : Pra riset Biro Pengadaan Barang dan Jasa Pemerintah Provinsi Lampung 2020

Dari keterangan tabel 1 dapat dilihat bahwa jumlah pelatihan yang rutin diadakan tiap tahunnya belum banyak diminati dan diikuti oleh pegawai Pojka di Lingkungan Biro Pengadaan Barang dan Jasa Pemerintah Provinsi Lampung sehingga sering terjadi kekeliruan atau kesalahan dalam melaksanakan kegiatan atau pekerjaan.

Pelatihan menurut Andrew F. Sikula yang dikutip Mangkunegara (2015:35) adalah suatu proses pendidikan jangka pendek yang mempergunakan prosedur sistematik dan terorganisir di mana pegawai non manajerial mempelajari pengetahuan dan keterampilan teknis dalam tujuan terbataas. Pelatihan juga merupakan usaha untuk memperbaiki penguasaan berbagai keterampilan dan teknik pelaksanaan kerja tertentu, terinci dan rutin (Handoko, 2016:28), dengan meliputi hal penting meliputi metode pelatihan, pelatih, fasilitas pelatihan, kebutuhan akan pelatihan, dukungan organisasi, manfaat pelatihan, materi pelatihan dan persepsi peserta pelatihan (Notoatmodjo, 2015:22).

Pelatihan terdiri dari 2 kategori pokok program pelatihan yaitu: metode on the job training (metode yang pelaksanaannya dilakukan di tempat kerja), dan metode off the job training 
(pelaksanaannya dilakukan di luar tempat kerja). Khusus metode metode off the job training, dibagi lagi berupa: simulasi dan presentasi informasi (Handoko, 2016:30).

Berdasarkan teori di atas, maka teori pelatihan yang digunakan adalah yang diungkapkan oleh Mangkuprawira (2014:30), pelatihan merupakan sebuah proses mengajarkan pengetahuan dan keahlian serta sikap agar karyawan semakin terampil dan mampu melaksanakan tanggung jawabnya dengan semakin baik, sesuai dengan standar. Kemudian indikator dari pelatihan yang digunakan dalam penelitian ini mengacu pada apa yang diungkapkan oleh Hariandja (2012:27), yaitu metode pelatihan on the job training, dan metode pelatihan off the job training.

Dalam Kasus ini, pelatihan berkaitan erat dengan adanya tuntutan tugas pekerjaan dari organisasi. Tuntutan tugas tersebut yang sering disebut sebagai beban kerja. Beban kerja yang dihadapi pegawai sudah tentu menuntut performa para pegawai dalam mengahadapi situasi pekerjaan yang distandarisasi oleh teknologi moderen.

Beban kerja menurut Meshkati dalam Astianto dan Suprihadi (2014) dapat didefinisikan sebagai suatu perbedaan antara kapasitas atau kemampuan pekerja dengan tuntutan pekerjaan yang harus dihadapi. Mengingat kerja manusia bersifat mental dan fisik, maka masing-masing mempunyai tingkat pembebanan yang berbeda-beda. Tingkat pembebanan yang terlalu tinggi memungkinkan pemakaian energi yang berlebihan dan terjadi overstress, sebaliknya intensitas pembebanan yang terlalu rendah memungkinkan rasa bosan dan kejenuhan atau understress. Oleh karena itu perlu diupayakan tingkat intensitas pembebanan yang optimum yang ada di antara kedua batas yang ekstrim tadi dan tentunya berbeda antara individu yang satu dengan yang lainnya. Menurut Hardi Pranoto di dalam Herdyana (2019:37) ada tiga cara yang dapat digunakan untuk mengukur beban kerja yaitu: Work Sampling, Study Time and Motion, Daily $\log$.

Berdasarkan teori diatas maka teori beban kerja yang digunakan adalah yang diungkapkan oleh Moekijat (2010:28), beban kerja adalah volume dari hasil kerja atau catatan tentang hasil pekerjaan yang dapat menunjukan volume yang dihasilkan oleh sejumlah pegawai dalam suatu bagian tertentu. Kemudian indikator dari beban kerja yang digunakan dalam penelitian ini mengacu pada faktor tuntutan tugas (task demands), usaha atau tenaga (effort), dan performansi (Hart dan Staveland dalam Astianto, 2014).

Kemampuan pegawai dalam melakukan sesuatu atau keahlian tertentu. kinerja pegawai sangatlah diperlukan, sebab kinerja akan diketahui mengenai seberapa jauh kemampuan pegawai dalam melaksanakan tugas yang dibebankan kepadanya (Sinambela, 2012).

Miftah (2013) mengemukakan bahwa kinerja Pegawai adalah hasil kerja secara kualitas dan kuantitas yang dicapai oleh seseorang Pegawai dalam melaksanakan tugasnya sesuai dengan tanggung jawab yang diberikan kepadanya. Oleh karena itu, dapat dikatakan bahwa kinerja Pegawai 
adalah prestasi kerja atau hasil kerja baik kualitas maupun kuantitas yang dicapai Pegawai dalam melaksanakan tugas kerjanya sesuai dengan tanggung jawab yang diberikan.

Robbins (2015) mengatakan bahwa kinerja juga diartikan sebagai hasil evaluasi terhadap pekerjaan yang dilakukan individu dibandingkan dengan kriteria yang telah ditetapkan bersama. Kinerja pegawai akan tercipta jika pegawai dapat melaksanakan tanggung jawabnya dengan baik.

Dalam Penelitian ini konsep kinerja mengacu pada apa yang diungkapkan oleh Sinambela (2012) yang mendefinisikan bahwa "Kinerja karyawan adalah kemampuan pegawai dalam melakukan sesuatu atau keahlian tertentu." Ada beberapa indikator Kinerja menurut (Mangkunegara, 2015) yaitu:

1. Faktor individual yang terdiri dari kemampuan dan keahlian, latar belakang dan demografi.

2. Faktor psikologis yang terdiri dari presepsi, attitude, personality, pembelajaran, motivasi.

3. Faktor organisasi yang terdiri dari sumber daya, kepemimpinan, penghargaan, struktur, job design.

Berikut di bawah ini gambar yang berisikan keterangan tentang pekerjaan yang dilaksanakan oleh pegawai Pokja di Lingkungan Biro Pengadaan Barang dan Jasa Pemerintah Provinsi Lampung.

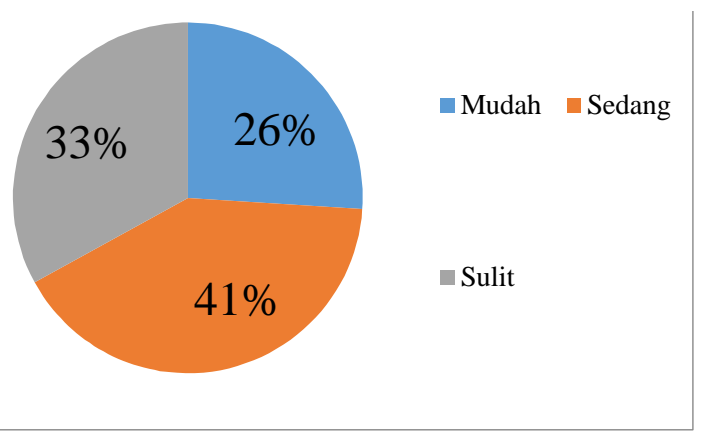

Gambar 1. Pendapat Pegawai tentang pekerjaan yang dilaksanakan

Sumber : Pra riset Biro Pengadaan Barang dan Jasa Pemerintah Provinsi Lampung 2020

Gambar 1 didapatkan dari silih pendapat beberapa pegawai yang berhasil diwawancarai penulis. Pada gambar di atas dapat dilihat bahwa sebanyak 33\% pegawai yang masih merasa kesulitan dalam menyelesaikan pekerjaan, sedangkan sebanyak $41 \%$ pegawai merasa tingkat kesulitannya sedang, dan sisanya sebanyak $26 \%$ pegawai yang merasa mudah dalam menyelesaikan pekerjaan. Dari keterangan gambar tersebut dapat ditarik kesimpulan awal bahwa pegawai Pokja di Lingkungan Biro Pengadaan Barang dan Jasa Pemerintah Provinsi Lampung masih mengalami 
banyak kendala penyelesaian pekerjaan yang dihadapi. Namun penulis perlu melakukan kajian dan meneliti lebih lanjut lagi.

Tingkat kesulitan masing-masing pekerjaan yang dihadapi oleh Pojka di Lingkungan Biro Pengadaan Barang dan Jasa Pemerintah Provinsi Lampung tentunya berdampak bagi kinerja dalam organisasi tersebut. Apabila pegawai sudah memiliki keterampilan dan skill yang mumpuni tentunya hal ini berdampak baik bagi kelancaran organisasi. Dalam awal observasi yang penulis lakukan, penulis menemukan indikasi bahwa masih terdapat pegawai yang menunda pekerjaan. Hal tersebut terlihat dalam tabel di bawah ini.

Tabel 2. Hasil Kerja Pegawai yang terjadi 5 Bulan Terakhir

\begin{tabular}{lcccc}
\hline \multirow{2}{*}{ Bulan } & Tahun & \multicolumn{3}{c}{ Pekerjaan } \\
\cline { 3 - 5 } & & Selesai & Tunda & Jumlah \\
\hline Februari & 2020 & $100 \%$ & $0 \%$ & $100 \%$ \\
Maret & 2020 & $100 \%$ & $0 \%$ & $100 \%$ \\
April & 2020 & $100 \%$ & $0 \%$ & $100 \%$ \\
Mei & 2020 & $71 \%$ & $29 \%$ & $100 \%$ \\
Juni & 2020 & $76 \%$ & $24 \%$ & $100 \%$ \\
\hline
\end{tabular}

Sumber : Pra riset Biro Pengadaan Barang dan Jasa Pemerintah Provinsi Lampung 2020

Dalam keterangan tabel 2 dalam jangka waktu 5 (lima) bulan terakhir di tahun 2020 pekerjaan yang diselesaikan oleh pegawai masih ditemukannya pekerjaan yang tertunda, hal ini disebabkan jumlah pekerjaan yang diberikan cukup banyak sering menimbulkan masalah terlambatnya penyelesaian kegiatan yang sudah dijadwalkan selain itu hasil kerja yang didapatkan belum seluruhnya maksimal disebabkan komposisi pegawai belum sepenuhnya baik. Dalam hal ini penulis perlu melakukan kajian lebih lanjut mengenai apa yang menyebabkan para pegawai masih sering menunda pekerjaan.

Berdasarkan permasalahan yang diuraikan diatas, maka dalam penelitian ini peneliti mencoba memfokuskan penelitian dengan melihat dan membuktikan model pada penyederhanaan fenomena yang terjadi untuk meneliti dan mengkaji lebih lanjut dengan cara menguji dan menganalisis "Pengaruh Pelatihan dan Beban Kerja Terhadap Kinerja Pokja di Lingkungan Biro Pengadaan Barang dan Jasa Pemerintah Provinsi Lampung”. Fokus penelitian pada konsep Pelatihan, Beban Kerja, dan Kinerja Pegawai.

Berdasarkan ulasan dalam latar belakang di atas, maka Pelatihan, Beban Kerja, dan Kinerja Pokja di Lingkungan Biro Pengadaan Barang dan Jasa Pemerintah Provinsi Lampung dalam membentuk Kinerja Pegawai, penelitian ini memiliki tujuan yaitu mengetahui pengaruh Pelatihan, Beban Kerja, dan Kinerja Pokja di Lingkungan Biro Pengadaan Barang dan Jasa Pemerintah Provinsi Lampung dan secara rinci mengetahui pengaruh Pelatihan terhadap Kinerja Pokja di Lingkungan Biro Pengadaan Barang dan Jasa Pemerintah Provinsi Lampung, pengaruh Beban Kerja 
terhadap Kinerja Pokja di Lingkungan Biro Pengadaan Barang dan Jasa Pemerintah Provinsi Lampung, pengaruh Pelatihan dan Beban Kerja secara bersama- sama terhadap Kinerja Pokja di Lingkungan Biro Pengadaan Barang dan Jasa Pemerintah Provinsi Lampung.

Penelitian ini diharapkan memberi manfaat untuk mengkaji lebih lanjut tentang penerapan pelatihan dan beban kerja pada kinerja Pokja di Lingkungan Biro Pengadaan Barang dan Jasa Pemerintah Provinsi Lampung yang digunakan untuk membentuk kebijakkan lebih lanjut.

\section{METODOLOGI PENELITIAN}

Desain Penelitian ini adalah survey dengan metode analitik korelasional. Kerlinger ( Sugiono; $2010: 3$ ) yang menyatakan bahwa " Pengertian survey adalah penelitian yang dilakukan pada populasi besar maupun kecil, tetapi data yang dipelajari adalah data dari sampel yang diambil dari populasi”. Dalam penelitian ini juga jenis yang digunakan adalah evaluasi.

\section{Populasi dan Sampel}

Berhubung jumlah populasi relatif kecil setelah dikurangi oleh penulis sebagai peneliti, maka penulis tidak mengadakan atau melakukan penarikan sampel untuk diteliti, karena dapat di jangkau seluruhnya. Hal ini berarti seluruh Pokja di Lingkungan Biro Pengadaan Barang dan Jasa Pemerintah Provinsi Lampung menjadi responden atau sumber data (sampel jenuh) dalam penelitian ini dengan cara penyebaran kuesioner dengan jumlah responden sebesar 50 responden.

\section{Teknik Pengumpulan Data}

Metode pengumpulan data yang dimaksud pada penelitian ini adalah menggunakan data pribadi subjek dan alat pengukuran atau instrumen. Alat pengukuran atau instrumen yang digunakan pada tiga konsep, yaitu skala konsep Pelatihan, Beban kerja dan Kinerja; data yang diperlukan dalam penelitian ini meliputi Sugiono, (2010):

a. Data Primer, yakni data yang diperoleh langsung melalui penelitian, baik melalui penggunaan kuesioner maupun wawancara.

b. Data skunder, data yang diperoleh dari teknik dokumentasi dengan memanfaatkan sumbersumber yang berkaitan dan dapat mendukung obyek yang akan diteliti. 


\section{Alat analisis}

Dalam hal ini r YX merupakan koefisien korelasi pearson untuk uji validitas dan alpha pada reliabilitas. Struktur hubungan variabel tersebut dapat dinyatakan ke dalam persamaan regresi, yaitu :

$$
\mathbf{Y}=\mathbf{b}_{\mathbf{o}}+\mathbf{b}_{1} \mathbf{x}_{1}+\mathbf{b}_{2} \mathbf{x}_{2}
$$

Jika hipotesis penelitian tersebut dinyatakan ke dalam hipotesis statistik adalah Arikunto (2012):

$$
\mathrm{F}_{\mathrm{O}}=\frac{(\mathrm{n}-\mathrm{k}-1) \sum_{\mathrm{i}=1}^{\mathrm{k}}\left(\mathrm{P}_{\mathrm{yxi}}\right) \mathrm{r}_{\mathrm{yxi}}}{\mathrm{k}\left(1-\sum_{\mathrm{i}=1}^{\mathrm{k}}\left(\mathrm{P}_{\mathrm{yxi}}\right) \mathrm{r}_{\mathrm{yxi}}\right)}
$$

Menurut Arikunto (2012) untuk memeriksa apakah hubungan pengaruh antara variabel X dan Y yang kedua-duanya pangkat ukuran ordinal digunakan korelasi Rank Spearman (Spearman's Coefficient of Rank Correlation ).

Perumusan matematisnya sebagai berikut :

$$
r S=\frac{\sum R(X) R(Y)-n \frac{(n+1)}{2} x^{2}}{\left.\sqrt{\left[\sum R(X)^{2}\right.}-n\left(\frac{n+1}{2}\right)\right]\left[\sum R(Y)^{2}-n\left(\frac{n+1}{2}\right)^{2}\right.} \bar{~}
$$

Keterangan :

$$
\begin{aligned}
\mathrm{Rs} & =\text { Koefisien korelasi Rank spearman } \\
\mathrm{R}(\mathrm{Xi}) & =\text { ranking dar variabel } \mathrm{X} \\
\mathrm{R}(\mathrm{Yi}) & =\text { ranking dari variabel } \\
\mathrm{n} & =\text { jumlah sampel }
\end{aligned}
$$

Kemudian untuk menguji apakah hasil koefisien ini signifikan ( nyata ) atau tidak, perlu dilakukan uji signifikan dengan alur pola umum pengujian, yaitu :

1) Membentuk hipotesis statistik.

Ho : ps $>0$; berarti ada hubungan pengaruh antara $\mathrm{X}$ terhadap $\mathrm{Y}$

2) Memberikan taraf kemaknaan ( level of significance 八

3) Statistik uji yang digunakan adalah uji t.

Untuk mengetahui apakah hubungan, pegaruh dan variabel tersebut betul-betul bermakna atau hanya terjadi secara kebetulan, perlu dilakukan uji signifikansi dengan menggunakan rumus uji t, yaitu Arikunto (2012):

$$
\mathrm{t}-\mathrm{h}=\operatorname{rs} \sqrt{\frac{n-2}{1-r^{2}}}
$$


Hasil perhitungan test signifikan ini, kemudian dibandingkan dengan nilai kritik t pada tabel distribusi stdent t, df.n-2 pada tingkat signifikansi untuk test dua sisi $\alpha=0,05$. Bila nilai t hitung lebih besar dari pada nilai t tabel ( $\mathrm{t}-\mathrm{h}>\mathrm{t}-\mathrm{t}$ ), maka hubungan antara dua variabel adalah signifikan. Sedangkan bila nilai t hitung lebih kecil kecil dari nilai $\mathrm{t}$ tabel $(\mathrm{t}-\mathrm{h}<\mathrm{t}-\mathrm{t})$, maka hubungan tersebut tidak signifikan, atau hubungan terjadi karena kebetulan saja.

1. Tentukan titik kritis dan daerah penolakan Ho.

2. Hitung nilai statistik uji t ( $\mathrm{t}$-uji )

\section{Koefisien Determinasi}

Koefisien determinasi merupakan bagian dari keragaman total dari variabel tak bebas yang dapat diperhitungkan oleh keragaman variabel bebas dihitung dengan koefisien determinasi dengan asumsi dasar faktor-faktor lain di luar variabel dianggap tetap atau konstan. Untuk mengetahui nilai koefisien determinasi, maka dapat dihitung dengan menggunakan rumus (Sugiyono, 2010):

$$
K D=r^{2} \times 100 \%
$$

Dimana :

$$
\begin{aligned}
\mathrm{KD} & =\text { Koefisien Determinasi } \\
\mathrm{r} & =\text { Kuadrat Koefisien Korelasi }
\end{aligned}
$$

Keterangan hasil korefisien :

$\mathrm{KD}=0 \%$, berarti pengaruh (variabel $\mathrm{X}$ ) terhadap (variabel $\mathrm{Y}$ ).

$\mathrm{KD}=100 \%$, berarti pengaruh (variabel $\mathrm{X}$ ) terhadap (variabel Y).

Hasil perhitungan pada koefisien determinansi dalam perhitungan penelitian ini dimasukkan dalam kategori pada tabel tersebut untuk diketahui besar pengaruhnya, dan dapat diartikan ketika hipotesis yang dilakukan terbukti signifikan.

\section{ANALISIS DAN PEMBAHASAN}

Pembuktian Hipotesis Diduga Pelatihan dan Beban Kerja berpengaruh terhadap Kinerja Pokja di Lingkungan Biro Pengadaan Barang dan Jasa Pemerintah Provinsi Lampung. Berdasarkan hasil analisis data maka hasil analisis yang didapatkan adalah sebagai berikut:

Tabel 3. Hasil Analisis Hipotesis

\begin{tabular}{|l|l|r|r|r|}
\multicolumn{7}{|c|}{ Model Summary } \\
\hline Model & $\mathrm{R}$ & R Square & $\begin{array}{c}\text { Adjusted R } \\
\text { Square }\end{array}$ & $\begin{array}{c}\text { Std. Error of } \\
\text { the Estimate }\end{array}$ \\
\hline 1 &, $915^{\mathrm{a}}$ &, 838 &, 831 & 1,22765 \\
\hline
\end{tabular}

a. Predictors: (Constant), Beban Kerja, Pelatihan

b. Dependent Variable: Kinerja 


\begin{tabular}{|c|c|c|c|c|c|c|}
\hline \multicolumn{7}{|c|}{ ANOVA $^{\mathrm{b}}$} \\
\hline Moc & & $\begin{array}{l}\text { Sum of } \\
\text { Squares }\end{array}$ & df & Mean Square & $\mathrm{F}$ & Sig. \\
\hline \multirow[t]{3}{*}{1} & Regression & 365,665 & 2 & 182,832 & 121,311 &, $000^{a}$ \\
\hline & Residual & 70,835 & 47 & 1,507 & & \\
\hline & Total & 436,500 & 49 & & & \\
\hline
\end{tabular}

a. Predictors: (Constant), Beban Kerja, Pelatihan

b. Dependent Variable: Kinerja

\begin{tabular}{|c|c|c|c|c|c|c|}
\hline \multicolumn{7}{|c|}{ Coefficients $^{a}$} \\
\hline \multirow{2}{*}{\multicolumn{2}{|c|}{ Model }} & \multicolumn{2}{|c|}{ Unstandardized Coefficients } & \multirow{2}{*}{$\begin{array}{c}\text { Standardized } \\
\text { Coefficients }\end{array}$} & \multirow[b]{2}{*}{$\mathrm{t}$} & \multirow[b]{2}{*}{ Sig. } \\
\hline & & $B$ & Std. Error & & & \\
\hline \multirow[t]{3}{*}{1} & (Constant) & 36,937 & 1,617 & & 22,842 &, 000 \\
\hline & Pelatihan & 2,776 & ,179 & 1,621 & 15,508 &, 000 \\
\hline & Beban Kerja & $-1,975$ & 145 & $-1,426$ & $-13,645$ &, 000 \\
\hline
\end{tabular}

a. Dependent Variable: Kinerja

Sumber Hasil Oleh Data PASW

Berdasarkan hasil uji tersebut maka didapatkan persamaan model regresi yang sebagai berikut :

$\begin{array}{lll}\mathbf{Y} & =36.932+2.776 \times 1+ & -1.975 X 2 \\ \mathbf{t}_{\text {hitung }} & =(22.842) & (15.508) \\ \mathbf{R}^{2} & =0,838 \\ \mathbf{F} & =121.311(\text { Prob.sig }=0,000) \\ \mathbf{N} & =\mathbf{5 0}\end{array}$

Dari hasil pengolahan regresi berganda yang telah didapatkan, maka dapat hasil penelitian dapat diinterpretasikan pada diketahui bahwa nilai $\mathrm{F}$ hitung sebesar 121.311 dan $\mathrm{F}$ signifikansi adalah $0.000<0.05$ yaitu pada tingkat signifikansi 95\% yang berarti sahih. Dan hasil estimasi dapat kita lihat bahwa nilai t hitung untuk variabel $(\mathrm{X} 1)$ sebesar 15.508 (Prob.sig. $=0,000)$ dan untuk variabel $(\mathrm{X} 2)$ sebesar -13.645 (Prob.sig. $=0,000$ ) yang berarti $\mathrm{t}$ hitung $>\mathrm{t}$ table dengan tingkat signifikansi $95 \%$ (persen) tetapi memiliki tanda negatif yang bebarti variabel ini memiliki kontribusi negatif. Kemudian koefisien determinasi X1, X2 - Y $\left(\mathrm{R}^{2}\right)$ cukup berarti yaitu sebesar 0.838 Berarti bahwa 83,8\% (persen) dari variasi perubahan pengaruh Pelatihan dan Beban Kerja dapat menjelaskan Kinerja Pokja di Lingkungan Biro Pengadaan Barang dan Jasa Pemerintah Provinsi Lampung. Sedangkan $16.2 \%$ (persen) sisanya adalah pengaruh dari variabel atau faktorfaktor lain diluar model. Kemudian Interpretasi fungsi regresi berganda dengan variabel X1 Pelatihan, Variabel X2 Beban Kerja dan Variabel Y Kinerja Pegawai adalah sebagai berikut:

- Konstanta $(\alpha)$

Konstanta $(\alpha)$ sebesar 36.932 berarti bahwa apabila variabel-variabel bebas yaitu $\left(\mathrm{X}_{1}\right)$, $\left(\mathrm{X}_{2}\right)$, sama dengan nol, maka (Y) nilainya 36.932 Angka pada konstanta tersebut mewakili bahwa jika tidak ada variabel (X1), dan variabel (X2) maka variabel (Y) akan bernilai 36.932 . 
- $\quad$ Koefisien $\left(\mathrm{X}_{1}\right)$

Nilai B menunjukan angka 2.776 yang berarti bahwa apabila terjadi kenaikan variabel (X1) sebesar 1 unit satuan maka menyebabkan variabel (Y) meningkat sebesar sebesar 2.776 x 1 unit satuan dengan tingkat signifikansi $95 \%$ dan menjaga variabel atau faktor-faktor lain adalah konstan atau tetap.

- $\operatorname{Koefisien}\left(\mathrm{X}_{2}\right)$

Dari model diketahui mempunyai nilai -1.975dan ini berarti bahwa apabila terjadi kenaikan variabel (X2) sebesar 1 unit satuan maka akan menjadikan variabel (Y) meningkat sebesar 1.975 x 1 unit satuan pada tingkat signifikansi $95 \%$ dan menjaga variabel atau faktor-faktor lain konstan atau tetap.

\section{Pembahasan Hasil Analisis}

Setelah dilakukan pengujian dan pembuktian hipotesis, selanjutnya dilakukan analisis untuk mengetahui kondisi parameter pada setiap variabel uji guna mendapatkan hasil yang lebih detail pada setiap variabelnya dengan menggunakan metode rata rata jawaban responden, Arikunto (2012).

Tabel 4. Hasil Rata - Rata Jawaban Angket

\begin{tabular}{|c|c|c|c|c|c|c|c|c|c|c|c|c|c|}
\hline Variabel & Butir & 1 & 2 & 3 & 4 & 5 & 6 & 7 & 8 & 9 & 10 & 11 & 12 \\
\hline Pelatihan & $\mathrm{X} 1$ & 2,22 & 2,44 & 2,60 & 2,80 & & & & & & & & \\
\hline Beban Kerja & $\mathrm{X} 2$ & 4,16 & 2,56 & 2,42 & 2,36 & 2,60 & 2,38 & 2,44 & & & & & \\
\hline Kinerja & Y & 2,04 & 2,32 & 2,22 & 2,46 & 2,02 & 2,44 & 2,12 & 2,42 & 2,60 & 2,24 & 2,18 & 2,44 \\
\hline
\end{tabular}

Berdasarkan hasil uji tersebut diketahui bahwa pada variabel X1 butir 1 memiliki rata - rata yang paling rendah, kemudian pada variabel X2 butir 4 memiliki rata - rata yang paling rendah dan pada variabel Y butir 5 adalah yang paling rendah data rata - ratanya. Kemudian guna memudahkan interpretasi dari hasil regresi linier berganda yang digabungkan dengan hasil rata - rata jawaban maka hasil analisis dirangkum dalam gambar rangkuman yang ditampilkan sebagai berikut: 


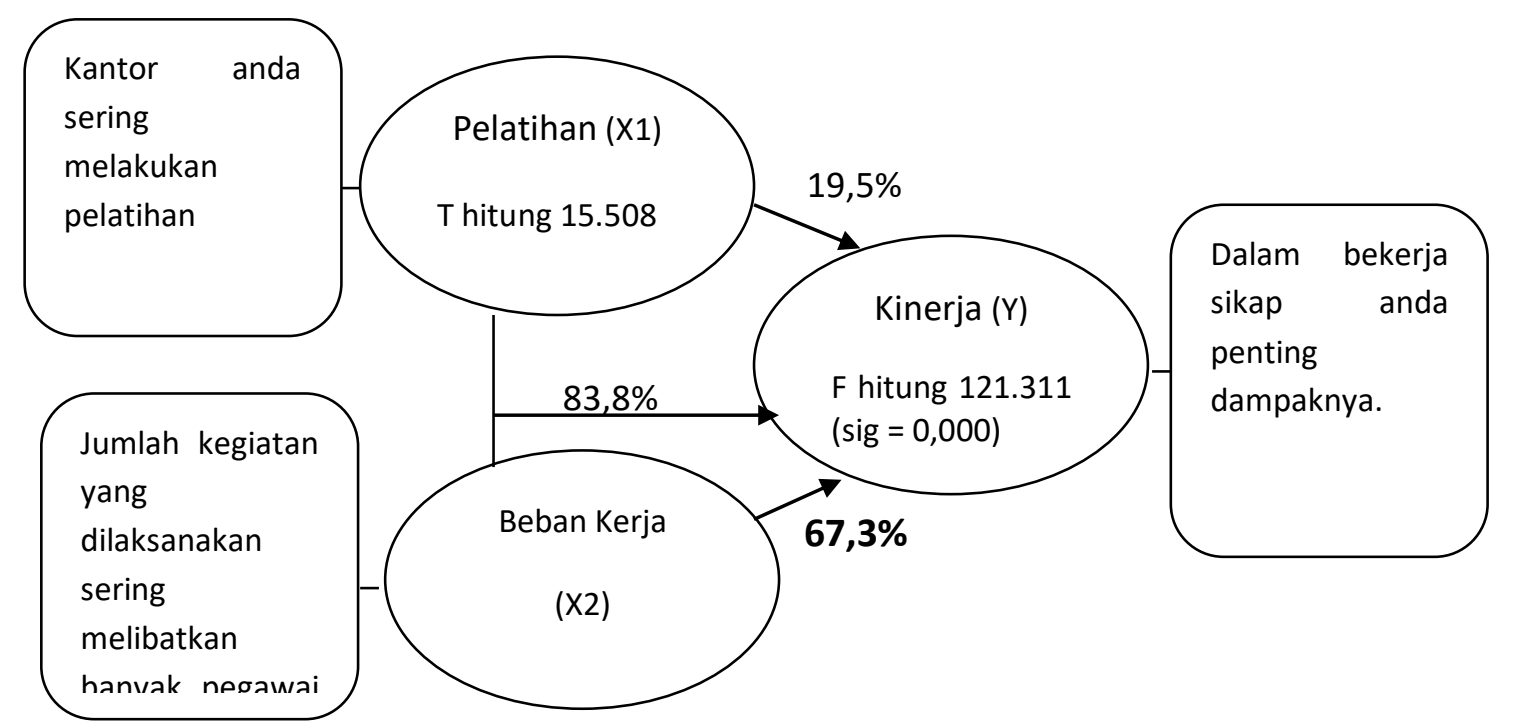

Gambar 3. Rangkuman Hasil Analisis Penelitian

Sumber Rangkuman Hasil Analisis PASW

\section{KESIMPULAN}

Pembahasan dari hasil analisis tersebut maka dapat diinterpretasikan bahwa Pelatihan dan Beban Kerja memiliki pengaruh yang cukup besar yaitu (83,8\%) terhadap Kinerja Pokja di Lingkungan Biro Pengadaan Barang dan Jasa Pemerintah Provinsi Lampung dengan variabel Beban Kerja sebagai variabel dominan yang mempengaruhi Kinerja Pokja di Lingkungan Biro Pengadaan Barang dan Jasa Pemerintah Provinsi Lampung dengan pengaruh sebesar (67,3\%) kemudian variabel ini juga memiliki kontribusi negatif yang berati beban kerja membikan hasil negatif jika terus ditambahkan pada pencapaian kinerja yang baik. Pada variabel pelatihan juga didapatkan bahwa butir 1 memiliki rata - rata yang paling rendah yaitu Kantor anda sering melakukan pelatihan. Pada Variabel Beban Kerja butir 4 memiliki rata - rata yang paling rendah yaitu pada butir Jumlah kegiatan yang dilaksanakan sering melibatkan banyak pegawai. Kemudian Pada variabel Kinerja Pokja di Lingkungan Biro Pengadaan Barang dan Jasa Pemerintah Provinsi Lampung butir 5 adalah yang paling rendah data rata - ratanya yaitu Dalam bekerja sikap anda penting dampaknya. Dari hasil pengolahan data juga didapatkan bahwa masih ada variabel lain yang ikut berpengaruh dan tidak diteliti kemudian belum dimasukkan tetapi diduga memiliki pengaruh pada pada perubahan Kinerja sebesar 16.2\% hal ini juga sesuai dengan apa yang dikemukakkan oleh Rizki (2019) dan hasil rangkuman penelitian yang dilakukan. 


\section{DAFTAR PUSTAKA}

Astianto, Suprihadi. 2014. Pengaruh Stress dan Beban Kerja Terhadap Kinerja Karyawan PDAM Surabaya. Tugas Akhir STIESIA Surabaya. https://ejournal.stiesia.ac.id.

Arikunto, Suharsimi.2012, Manajemen Penelitian, Jakarta, Rineka Cipta.

Aulia, Ahmad Fauzan. 2016. Pengaruh Pelatihan dan Stress Kerja Terhadap Kinerja Pegawai (Studi Kasus Pada Dirtektorat Jendral Sumber Daya Air Kementerian Pekerjaan Umum dan Perumahan Rakyat). Skripsi Universitas Islam Negeri Syarif Hidayatullah.

Handoko, T. Hani. 2016. Manajemen Sumber Daya Manusia, Yogyakarta: Penerbit BPFE

Hariandja. 2012. Manajemen Sumber Daya Manusia: Teori Pengadaan, Pengembangan, Penkompensasian dan Peningkatan Produktivitas Pegawai. Jakarta: Grasindo.

Hasibuan, Melayu SP, 2013. Manajemen Sumber Daya Manusia, Edisi Revisi Bumi Aksara.

Herdyana, Rizki. 2019. Pengaruh Beban Kerja dan Pelatihan Kerja Terhadap Kinerja Pegawai Pada Dinas Pemadam kebakaran Soreang kabupaten Bandung. Tesis Pascasarjana Universitas Pasundan. P.37

Mangkuprawira. 2014. Manajemen Sumber Daya Manusia Strategik (edisi 2). Jakarta: Ghalia Indonesia.

Mangkunegara, 2015. Perilaku dan Budaya Organisasi, Jakarta, Refika Aditama.

Mayhana, Zahratun. 2016. Pengaruh Pelatihan dan Beban Kerja Terhadap Kinerja Karyawan (studi Kasus Pada Kantor Pusat PT. Angkasa Pura II Persero). Tesis Universitas Mercu Buana.

Miftah Thoha, 2013. Prilaku Organisasi Konsep Dasar Dan Aplikasinya. Jakarta: Raja Grafindo Persada.

Moekijat. 2010. Manajemen Tenaga Kerja Dan Hubungan Kerja. Pionir Jaya, Bandung P 33

Notoadmodjo. 2014. Teori Perilaku Manusia. Jakarta: PT. Rineka Cipta.

Pranoto, Hadi. 2012. Analisis Beban Kerja. Jakarta: PPM Manajemen.

Rivai, Veithzal dan Sagala, 2014, Manajemen Sumber Daya Manusia untuk Perusahaan Dari Teori ke Praktik, Jakarta, Rajawali Press.

Robbins, Stephen P, 2015, Organizational Behavior, New Jersey: Prentice Hall International.

Sedarmayanti, M. Pd, 2013, Sumber Daya Manusia Dan Produktifitas Kerja,

CV. Mandar Maju, Bandung

Sugiono, 2010. Metode Penelitian Pendidikan, Penerbit Alfabeta, Bandung.

Sinambela, Poltak. Lijan. 2012. Kinerja Pegawai Teori Pengukuran dan Implikasi. Yogyakarta: Graha Ilmu 
Triani, Linda. 2019. Pengaruh Beban Kerja, Pendidikan dan Pelatihan Terhadap Kinerja Bidan Puskesmas di kabupaten Lampung Barat. Tesis Pascasarjana Unversitas Lampung. 